\title{
Regeneration of emergence profile with soft tissue graft and wide computer aided design/computer aided mamufacturing abutments: a clinical report
}

\author{
Min-Kyung Kim', Ji-Hun Lee1, Seung-Geun Ahn', Kyung-A Kim², Jae-Min Seo * \\ 'Department of Prosthodontics, School of Dentistry and Institute of Oral Bio-Science, Chonbuk National University, Jeonju, \\ Republic of Korea \\ ${ }^{2}$ Department of Dentistry, School of Medicine, Eulji University, Daejeon, Republic of Korea
}

\begin{abstract}
Fixed restoration using implants for patients with posterior partial edentulism is generalized technique. As patient demands increase, the functional and esthetic implant restoration to achieve similar results to lost natural teeth is becoming an important issue. It is inevitable to use customized CAD/CAM abutments rather than ready-made abutments for the creation of implant prosthesis which closely resembles natural teeth. Using CAD/CAM abutment made it possible to obtain natural emergency profiles for posterior implant prostheses, ensuring more comfortable, efficient management of oral hygiene. However, keratinized gingiva with sufficient width and height for a natural emergence profile is required to use a large diameter CAD/CAM abutment which ensures stability and esthetics of hard/soft tissue around the implants. In this case, for esthetical and functional implant zirconia prosthesis, soft tissue graft was performed and customized CAD/CAM abutments were used following ridge augmentation, sinus graft and implantation. Satisfactory results were obtained functionally and esthetically through periodic clinical evaluation, and I hereby report this case. (J Dent Rehabil Appl Sci 2015;31(4):364-70)
\end{abstract}

Key words: CAD/CAM abutment; emergence profile; soft tissue graft

\begin{abstract}
서론
구치부 부분 무치악 환자에서 임플란트를 이용한 고정 성 보철수복은 일반화된 술식이다. 임플란트 보철의 기 능만이 강조되던 과거에는 구치부 임플란트 주위에 각화 치은이 없거나 지대주의 금속색이 구강 내로 노출되더라 도, 골유착만 성공적이라면 임상적으로 만족스러운 결과 를 얻은 것이라고 생각하였다. 그러나 최근에는 환자의 요구사항이 높아지면서 상실된 자연치아와 유사한 형태 로의 기능적이고 심미적인 회복이 임플란트 보철수복의

\footnotetext{
*Correspondence to: Jae-Min Seo Bio-Science, Chonbuk National University, 567, Baekje-daero, Dukjin-gu, Jeonju, 54896 , Repulic of Korea

Tel: +82-63-250-2696, Fax: +82-63-250-2218, E-mail: jmseo@jbnu.ac.kr
}

Professor, Department of Prosthodontics, School of Dentistry and Institute of Oral Received: July 17, 2015/Last Revision: October 12, 2015/Accepted: December 5, 2015
\end{abstract}

중요한 문제로 대두되고 있다.

이와 같이 기능적이고 심미적이며, 자연치아와 유사한 형태의 임플란트 보철물의 제작을 위해서는 기성 지대 주 보다는 customized computer aided design/computer aided mamufacturing $(\mathrm{CAD} / \mathrm{CAM})$ 지대주를 사용하는 것이 유리하다. 그 이유는 customized CAD/CAM 지대 주가 보다 편하고 효율적인 구강위생관리를 보장하는 자 연스러운 출현윤곽을 가진 보철물 제작을 가능토록 하기 때문이다(Fig. 1). 그러기 위해서는 구치부의 경우 큰 폭 의 $\mathrm{CAD} / \mathrm{CAM}$ 지대주가 종종 필요하며 이를 사용하기

Copyright@ 2015 The Korean Academy of Stomatognathic Function and Occlusion. (c) It is identical to Creative Commons Non-Commercial License. 
A
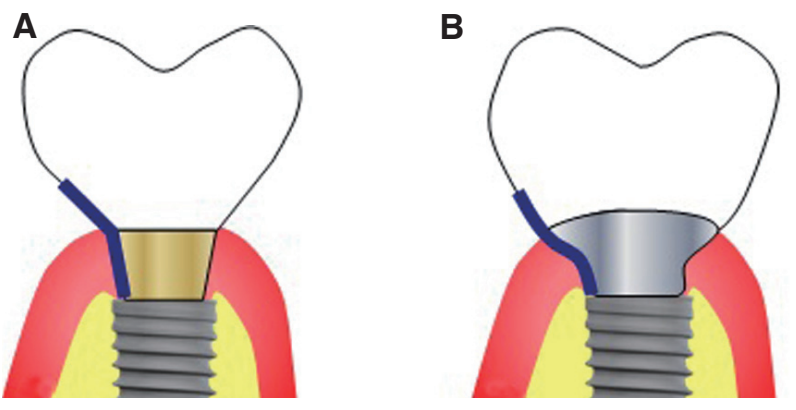

Fig. 1. The differences of emergency profile between ready-made abutment and customized CAD/CAM abutment. (A) An emergence profile of implant prosthesis using ready-made abutment. (B) An emergence profile of implant prosthesis using of customized CAD/CAM abutment.

위해서는 임플란트 주위에 충분한 폭과 높이를 가지는 각화치은이 존재해야만 한다. ${ }^{1,2}$ 이는 향후 임플란트 주 위 경조직 및 연조직의 안정성과 심미성을 보장한다. ${ }^{1}$

여러 문헌에서 임플란트 주위에는 최소 $2 \mathrm{~mm}$ 의 각화 치은이 있어야 한다고 추천하고 있다. ${ }^{3-5}$ 이는 치태축적 을 감소시켜 임플란트 유지를 도우며 치은퇴축을 예방 한다. ${ }^{6}$ 만약 긴 치아상실기간이나 골이식술 등으로 인하 여 임플란트 주위에 각화치은이 부족한 경우에는 연조 직 증대술을 시행함으로써 심미적이고 기능적인 임플란 트 보철물의 제작을 가능하게 할 뿐만 아니라, 박테리아 침임을 막는 임플란트 구조물의 변연폐쇄를 제공하고 구강위생관리를 용이하게 하여 향후 임플란트 주위염의 발생 가능성을 감소시킬 수 있다..$^{7-9}$

본 증례는 골이식술 및 임플란트 식립 후 각화치은 이 부족하고 협측전정이 소실된 환자에서 유리치은이 식술'을 시행하여 충분한 각화치은의 양을 확보하였고 customized $\mathrm{CAD} / \mathrm{CAM}$ 지대주 및 지르코니아 보철물
을 이용하여 수복한 증례로 주기적인 내원 및 검사를 통 해 기능적, 심미적으로 만족할만한 결과를 얻었기에 보 고하고자 한다.

\section{증례 보고}

상기환자는 70세 여성으로 상악 좌측 구치부와 하악 우측 구치부의 치아상실을 주소로 본원 보철과에 내원 하였다. 특별한 병력은 없었다. 상악 좌측 제 1 대구치와 제2대구치는 6 개월 전 발치하였고 임상적, 방사선학적 소견상 상악 좌측 무치악부위의 치조골이 흡수된 상태 로 임플란트를 식립하기에 치조골의 폭과 높이가 충분 하지 않았다(Fig. 2, 3A, 3B).

따라서, 상악 우측 무치악 부위에 치조골 증대술 및 상악동 거상술과 임플란트 식립술을 시행한 후 customized CAD/CAM abutment 및 지르코니아 보철 물을 이용하여 수복하기로 계획하였다.

상악 우측 무치악 부위를 stent를 이용하여 컴퓨터단 층촬영 영상 채득하여 관찰해본 결과, 이상적인 위치에 임플란트를 식립할 수 없는 치조골의 형태와 폭을 보였 다(Fig. 3A, 3B). 특히 \#26 부위에서 그 양상은 매우 심

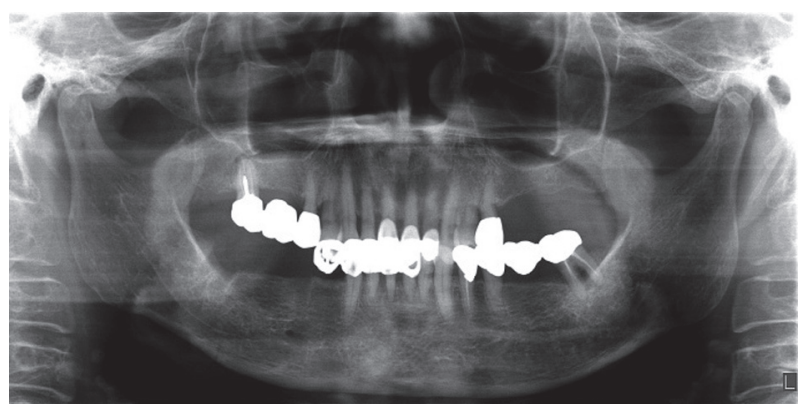

Fig. 2. Panoramic X-ray finding at first visit.

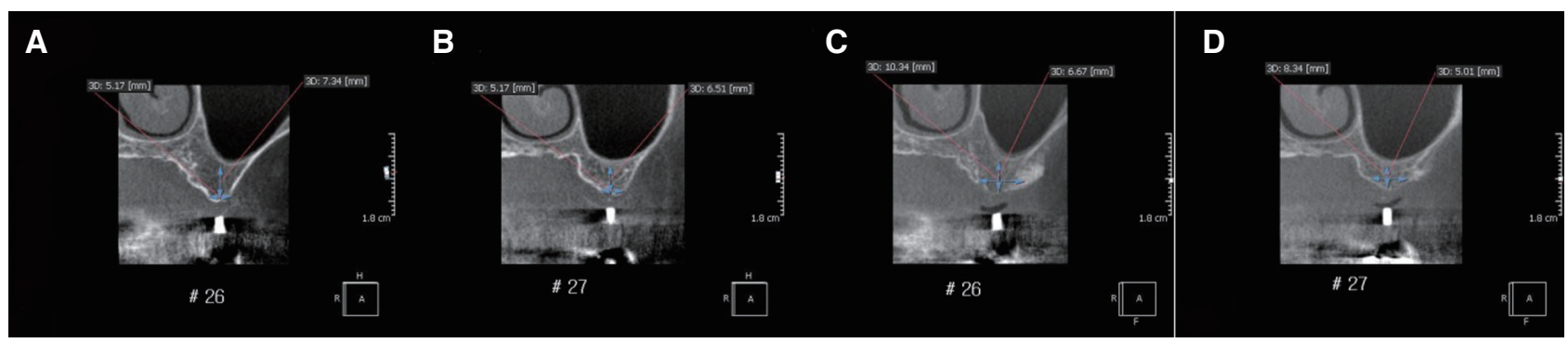

Fig. 3. Computed tomography (CT) images on \#26, 27 before and after ridge augmentation. (A, B) Insufficient height and width of alveolar bone for \#26, 27 implantation before ridge augmentation. (C, D) The grafted bone on buccal surface provides sufficient width of alveolar bone for \#26, 27 implantation after ridge augmentation. 
하였다. 이에 부족한 치조골 폭을 확보하고 대합되는 하 악치아와 조화로운 위치에 임플란트를 식립하기 위해 치조골 증대술을 계획하였다.

협측 골결손부는 좌측 하악지에서 채취한 자가골과 이종골(Bio-Oss, Geistlich, Wolhusen, Switzerland)을 1: 1로 혼합하여 적용하고 Fibrin glue (Tissel, Baxter AG, Vienna, Austria)를 이용하여 이식부를 고정하였으 며 차폐막(Bio-Gide, Geistlich)으로 덮어 골유도재생술 을 시행하였다(Fig. 3C, 3D).

치조골 증대술 시행 후 6 개월 동안의 골화 과정을 거친 후, 치조골의 높이를 얻기 위해 lateral approach technique을 사용하여 상악동저 점막을 거상하였고 이 종골(Bio-Oss와 Endobon, Xenograft Granules, Biomet $3 i$, Vicenza, Italy)을 압축하여 적용하는 상악동 이식술 을 시행하였다.

동시에, \#26, 27 위치에 직경 $5.0 \mathrm{~mm}$, 길이 $12 \mathrm{~mm}$ 의 임플란트(Superline, Dentium, Seoul, Korea) 두 개를 식 립하였다(Fig. 4).

치조골 증대술과 상악동 이식술 등의 과정은 부족한 치조골의 폭과 높이를 증가시키지만 협측판막의 이동으 로 불가피하게 각화치은이 소실되고 구강전정이 낮아지 게 된다. ${ }^{10}$ 임플란트 식립 6 개월 후 이차 수술을 통하여 치유지대주를 연결하고 구개측 각화치은을 이용하여 협 측의 부착치은을 확보하려 하였으나 그 양이 부족하고 낮아진 협측전정에는 개선이 보이지 않아 보철 수복 후 구강위생관리가 불리할 것으로 예상되었다(Fig. 5).

따라서, 낮은 협측 전정의 높이와 좁은 부착치은의 폭 을 개선하기 위해 치근변위판막술과 유리치은이식술 을 시행하였다. 먼저 지대주의 협측에 부분층 판막을 형 성하여 치근단 방향으로 위치시킨 후 하방의 골막에 봉
합하여 고정하였고(apically positioned flap) 노출된 부 위는 조직을 정리하여 균일한 골막에 의해 수여부가 형 성되도록 하였다. 수여부의 크기와 모양을 측정하여 동 측 제 1 소구치에서 제 2 대구치 부위의 경구개에 작도 후, 상피를 포함하는 결합조직(free gingiva)을 채취하여 수 여부위에 이식 후 이식편의 동요 및 이식편과 수여부 사이에 사강(dead space)이 없도록 골막에 단단히 봉합 하였다. 공여부는 환자의 혈액에서 채취한 platelet rich fibrin (PRF)를 눌러 막으로 만들어 환부를 덮고 봉합함 으로서 출혈과 자극을 최소화하도록 하였다(Fig $6 \mathrm{~A}, 6 \mathrm{~B}$, 6C). 연조직 이식 후 4주 체크 시, 수술 부위의 협측 전 정이 치근단 방향으로 깊어진 것을 관찰할 수 있었다. 또한, 협측 부착치은의 양과 치유지대주 주변의 연조직 두께도 충분히 증가되었다(Fig. $6 \mathrm{D}$ ). 이는 넓은 직경의 customized $\mathrm{CAD} / \mathrm{CAM}$ 지대주의 사용을 가능하게 할 것이다.

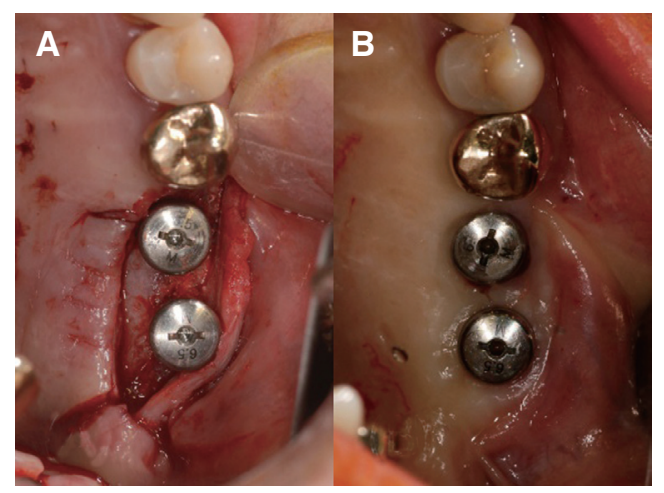

Fig. 5. Occlusal view of clinical images at second surgery stage. (A) Occlusal view before second surgery, (B) Occlusal view of after second surgery: The narrow attached gingiva and shallow buccal vestibule.
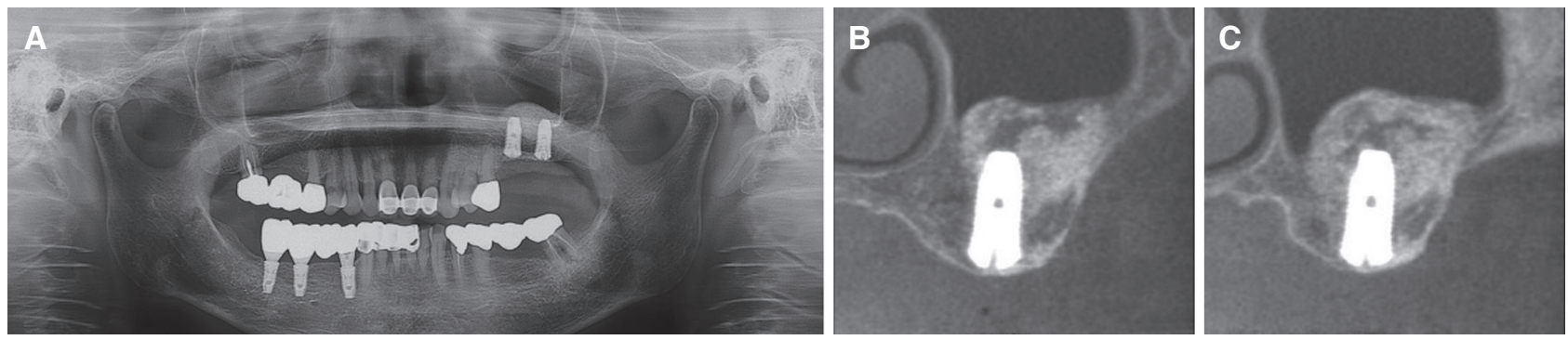

Fig. 4. Panoramic X-ray finding and CT images after \#26, 27 implantation. (A) Panoramic X-ray view, (B, C) CT images of 4 months after \#26, 27 implantation - gaining appropriate height from alveolar ridge to sinus floor for implant fixtures through sinus graft. 


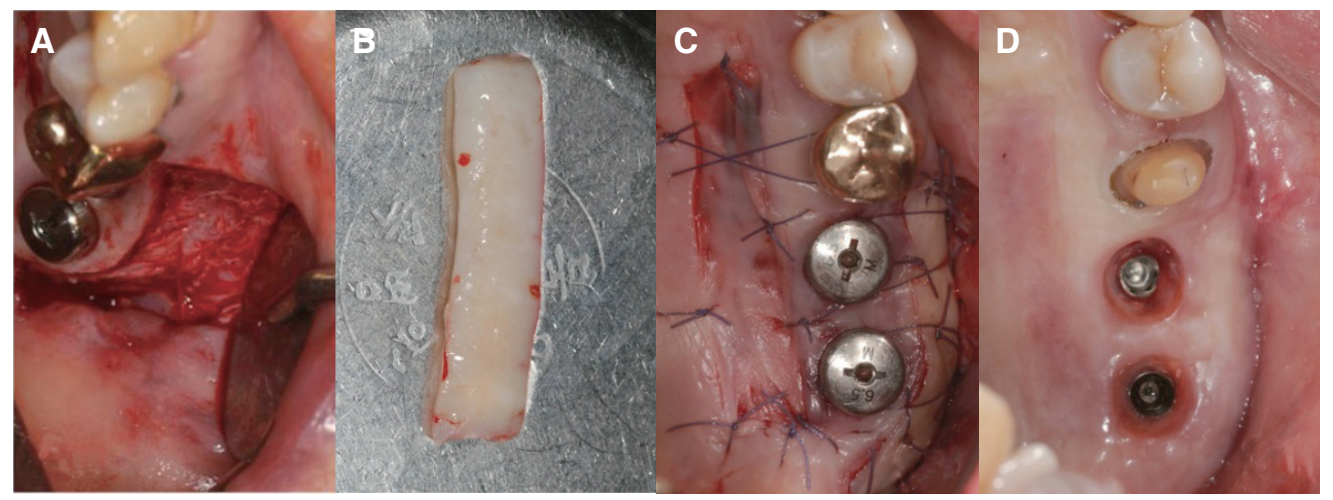

Fig. 6. Clinical images at soft tissue graft. (A) Vestibules are disclosed by apically repositioning the buccal partial thickness flap, (B) The graft harvested from the donating palate was cut in the shape of the recipient site, (C) Occlusal view after free gingival graft, (D) Occlusal view 4 weeks after soft tissue graft.
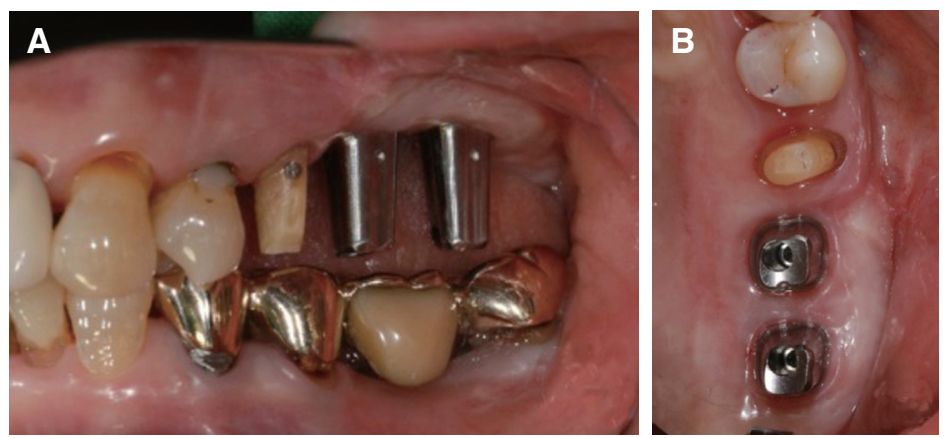

Fig. 7. Clinical view at customized CAD/CAM abutment connection to \#26, 27 implant. (A) Buccal view, (B) Occlusal view.
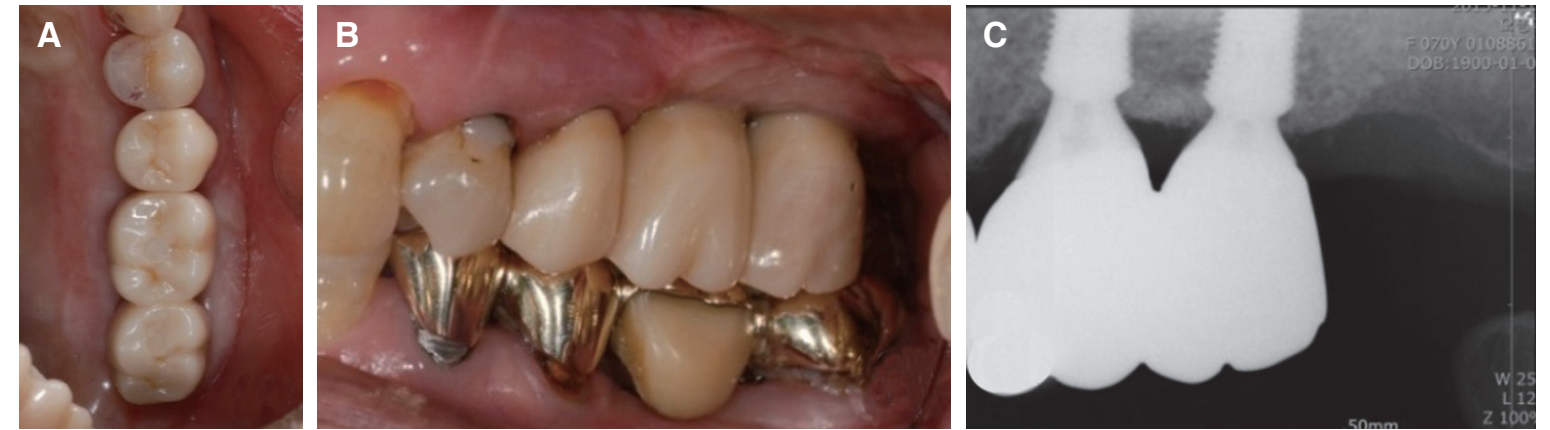

Fig. 8. Clinical view and radiographic image at definitive prosthesis delivery (A) Occlusal view, (B) Buccal view: wide attached gingiva and deep vestibule were observed, (C) Periapical standard radiographic image of \#26, 27 implant after definitive prosthesis delivery.

연조직 이식술 후 6주에 \#25, 자연치아와 \#26, 27 임플란트를 위한 최종인상채득을 시행하였고 티타늄 customized CAD/CAM 지대주를 제작하였다(Fig. 7). Customized CAD/CAM 지대주의 사용은 인접치아와 의 삽입로를 평행하게 맞출 수 있고 치간공극을 적절하 게 부여할 수 있어 칫솔 사용이 용이하고 자연스러운 출 현윤곽 및 치은형태를 형성해 줄 수 있으며 식편압입의
가능성을 낮춰준다. ${ }^{11}$

\#25 자연치아와 \#26, 27 임플란트에 단일구조 지르 코니아 보철물을 이용하여 최종수복하였다. 보철물 하 방으로 충분한 폭의 부착치은과 깊은 협측 전정이 관찰 되며 적절한 치간공극이 확보되었다. 또한 비교적 상악 대구치와 유사한 출현윤곽을 최종 보철물에 부여해주도 록 노력하였다(Fig. 8). 


\section{고찰}

아직 논의되고 있으나 최근의 여러 문헌에 의하면, 임 플란트 주위에 최소 $2 \mathrm{~mm}$ 의 각화치은이 추천된다고 하 였다. ${ }^{3-5}$ 발치 후 오랜 기간이 지났거나 골이식술을 시행 한 경우 임플란트 주위에 각화치은이 소실되어 충분히 존재하지 않게 되는데, 이럴 경우 연조직 이식술을 시행 하여 좀 더 심미적이고 기능적인 임플란트 보철물을 제 작할 수 있다.

임플란트 주변의 충분한 각화치은은 넓은 customized $\mathrm{CAD} / \mathrm{CAM}$ 지대주와 최종 보철물을 이용하여 자연치 아와 유사한 자연스러운 출현윤곽을 재현해줄 수 있도 록 지지해준다. ${ }^{11,12}$ 만약 임플란트 주변에 충분한 각화치 은이 없는 경우에서 넓은 지대주를 무리하게 사용하게 될 경우에는 종종 지대주가 점막이나 비각화치은을 침 범하게 되어 치은 퇴축으로 인한 치관길이의 증가나 외 부자극에 취약해지게 된다.

또한 각화치은은 칫솔질 등의 기계적 자극에 덜 민감 하고 치은퇴축 등을 예방하여 구강위생 관리를 더욱 용 이하게 해주고 임플란트와 치주조직간의 변연봉쇄를 제 공하여 임플란트 주위염의 발생을 낮출 수 있다. ${ }^{7,913}$

과량의 골이식술이나 수 회에 걸친 수술은 종종 협측 전정을 얕아지게 만든다. 이를 개선하기 위해 치근단 변 위 판막술로 전정을 깊게 하고 부가적으로 연조직 이식 술을 시행하여 부족한 각화치은을 보충 해 음식물의 저 류를 막고 칫솔질의 접근을 용이하게 한다. ${ }^{3,14,15}$

최근 들어 $\mathrm{CAD} / \mathrm{CAM}$ 기술이 발전하면서 이를 이 용하여 임플란트의 지대주도 환자 개개인의 치은상태 에 최적화되도록 제작할 수 있게 되었다. Customized $\mathrm{CAD} / \mathrm{CAM}$ 지대주는 마무리선을 술자나 기공사가 환 자 구강에 맞춰 정밀하게 조절할 수 있으며, ${ }^{16}$ 부착치은 의 폭과 넓이가 충분한 경우에 한해서 자연치아와 유사 한 출현윤곽을 재현할 수 있도록 크게 제작될 수 있다. 자연치아와 유사한 출현윤곽의 재현은 환자의 심미적, 심리적 만족도를 충족시켜줄 뿐 아니라 음식물의 저류 나 자극을 예방하여 구강위생관리의 편안함과 장기적인 예후를 보장할 수 있을 것이라 사료된다. ${ }^{15,17}$

또한, customized CAD/CAM 지대주는 인접치아와 의 삽입로를 평행하게 맞추고 각 지대주의 크기를 조절 하여 최종수복물의 치간공극을 적절하게 부여해줄 수 있다.

본 증례에서는 골이식, 임플란트 식립 및 연조직 이식
을 시행하고 customized CAD/CAM 지대주를 이용하 여 지르코니아 보철 수복을 완료하였다. 장기간에 걸친 주기적 관찰 후 기능적 심미적으로 만족할만한 결과를 얻었기에 보고하는 바이다.

\section{결론}

상실된 구치부를 임플란트를 이용해 심미적, 기능적 으로 수복하기 위해서는 경조직 및 연조직의 지지가 필 수적이다. 적절한 경.연조직 증대술을 동반한 주의 깊은 수술과 더불어, 조화롭고 자연스러운 연조직 재현을 위 한 customized CAD/CAM 지대주의 사용은 최종 보철 물을 자연치아와 유사한 형태의 심미보철이 가능하도록 만들며, 이는 구강위생 관리의 용이성 뿐만 아니라 향후 안정된 임플란트 보철의 예후를 보장한다.

\section{ORCID}

Min-Kyung Kim http://orcid.org/0000-0003-4410-2538

Ji-Hun Lee http://orcid.org/0000-0002-5954-0453

Seung-Geun Ahn http://orcid.org/0000-0002-9105-931X

Kyung-A Kim http://orcid.org/0000-0002-2923-5351

Jae-Min Seo http://orcid.org/0000-0001-5095-4046

\section{References}

1. Brito C, Tenenbaum HC, Wong BK, Schmitt C, Nogueira-Filho G. Is keratinized mucosa indispensable to maintain peri-implant health? A systematic review of the literature. J Biomed Mater Res B Appl Biomater 2014;102:643-50.

2. Alshiddi IF, Dent DC. Accurate registration of peri-implant soft tissue to create an optimal emergence profile. Contemp Clin Dent 2015;6:S122-5.

3. Landi L, Sabatucci D. Plastic surgery at the time of membrane removal around mandibular endosseous implants: a modified technique for implant uncovering. Int J Periodontics Restorative Dent 2001;21:280-7.

4. Lang NP, Löe H. The relationship between the width of keratinized gingiva and gingival health. J Periodontol 1972;43:623-7.

5. Schrott AR, Jimenez M, Hwang JW, Fiorellini J, 
Weber HP. Five-year evaluation of the influence of keratinized mucosa on peri-implant soft tissue health and stability around implants supporting full-arch mandibular fixed prostheses. Clin Oral Implants Res 2009;20:1170-7.

6. Yeung SC. Biological basis for soft tissue management in implant dentistry. Austrian Dent J 2008; 53 suppl 1:S39-42.

7. Roccuzzo M, Grasso G, Dalmasso P. Keratinized mucosa around implants in partially edentulous posterior mandible: 10 -year results of a prospective comparative study. Clin Oral Implants Res 2015 Feb 23. doi: 10.1111/clr.12563. [Epub ahead of print].

8. Lin GH, Chan HL, Wang HL. The significance of keratinized mucosa on implant health: a systematic review. J Periodontol 2013;84:1755-67.

9. Wang Y, Zhang Y, Miron RJ. Health, maintenance, and recovery of soft tissue around implants. Clin Implant Dent Relat Res 2015 Apr 15. doi: 10.1111/ cid.12343. [Epub ahead of print].

10. Lee KH, Kim BO, Jang HS. Clinical evaluation of a collagen matrix to enhance the width of keratinized gingiva around dental implants. J periodontal Implants Sci 2010;40:96-101.

11. Su H, Gonzalez-Martin O, Weisgold A, Lee E. Considerations of implant abutment and crown contour: critical contour and subcritical contour.
Int J Periodontics Restorative Dent 2010;30:335-43.

12. Son MK, Jang HS. Gingival recontouring by provisional implant restoration for optimal emergence profile: report of two cases. J Periodontal Implants Sci 2011;41;302-8.

13. Bouri A Jr, Bissada N, Al-Zahrani MS, Faddoul F, Nouneh I. Width of keratinized gingiva and the health status of the supporting tissue around dental implants. Int J Oral Maxillofac Implants 2008;23: 323-6.

14. Daniel S. Thoma, Ronald E. Jung. Efficacy of soft tissue augmentation around dental implants and partially edentulous areas: a systematic review. J Clin Periodontol 2014;41 suppl 15:S77-91.

15. Thoma DS, Benić GI, Zwahlen M, Hammerle CH, Jung RE. A systematic review assessing soft tissue augmentation techniques. Clin Oral Implants Res 2009;20 Suppl 4:146-65.

16. Fuster-Torres MA, Albalat-Estela S, Alcaniz-Raya M, Penarrocha-Diago M. CAD/CAM dental system in implant dentistry: update. Med Oral Patol Oral Cir Bucal 2009;14:E141-5.

17. Parpaiola A, Norton MR, Cecchinato D, Bressan E, Toia M. Virtual abutment design: a concept for delivery of CAD/CAM customized abutmentsreport of a retrospective cohort. Int J Periodontics Restorative Dent 2013;33:51-8. 


\section{연조직 이식술과 넓은 computer aided design/computer aided mamufacturing 지대주를 이용한 임플란트 고정성 보철물의 출현윤곽 재현}

김민경 ${ }^{1}$, 이지훈 ${ }^{1}$, 안승근 ${ }^{1}$, 김경아 ${ }^{2}$, 서재민 ${ }^{1 *}$

${ }^{1}$ 전북대학교 치의학전문대학원 치과보철학교실 및 구강생체과학연구소

${ }^{2}$ 을지대학교 의과대학 치과학교실

최근 구치부 부분 무치악 환자의 임플란트 보철 수복은 기능적뿐만 아니라 심미적으로도 환자의 만족을 이끌어내야 하 는 과제를 안고 있다. 이렇게 환자의 요구가 높아지면서 상실된 자연치아와 유사한 형태의 임플란트 보철을 사용한 구 강회복이 보철수복의 중요한 이슈가 되고 있다. 이를 위해서는 기성 지대주 보다는 더 넓은 customized CAD/CAM 지 대주를 사용함으로써 자연스러운 출현윤곽을 재현할 수 있다. 넓은 지대주를 지지해주기 위해서는 충분한 폭과 높이를 가지는 각화치은이 존재해야 하는데, 만약 긴 치아상실기간이나 골이식술 등으로 인해 임플란트 주위에 각화치은이 부 족한 경우에는 연조직 증대술을 시행하는 것이 추천된다. 이러한 과정을 통해 심미적이고 기능적인 임플란트 보철 제 작이 가능하며 구강위생관리를 용이하게 하고 향후 임플란트 주위염의 발생 가능성을 감소시킨다. 본 증례는 구치부 부분 무치악 환자에서 골이식술, 상악동 이식술, 임플란트 식립술 및 연조직 이식술을 사용하여 부족한 치조골과 각화 치은 및 협측전정을 회복하였으며, customized CAD/CAM 지대주와 지르코니아 보철물을 이용하여 수복한 증례로 주 기적인 내원 및 검사를 통해 기능적, 심미적으로 만족할만한 결과를 얻었기에 이 사례를 보고하고자 한다.

(구강회복응용과학지 2015;31 (4):364-70)

주요어: $\mathrm{CAD} / \mathrm{CAM}$ 지대주; 출현윤곽; 연조직 이식술

*교신저자: 서재민

(54896) 전북 전주시 덕진구 백제대로 567 전북대학교 치의학전문대학원 보철학교실 및 구강생체과학연구소

Tel: 063-250-2696 | Fax: 063-250-2218 | E-mail: jmseo@jbnu.ac. kr

접수일: 2015년 7월 17일 | 수정일: 2015년 10월 12일 | 채택일: 2015년 12월 5일 